\title{
Analisis Kemampuan Koneksi Matematis Siswa dalam Memecahkan Masalah Geometri Berdasarkan Tingkat Berpikir Van Hiele di kelas VIII Mts Al-Fatah Singkawang.
}

\author{
Nurul Hayati ${ }^{1}$, Rika Wahyuni ${ }^{2}$, Nurhayati ${ }^{3}$ \\ Pendidikan Matematika, STKIP Singkawang, Singkawang, Indonesia \\ hayatiuul95@gmail.com ${ }^{1}$, rikawahyuni142@gmail.com ${ }^{2}$,nurhayati@stkipsingkawang.ac.id ${ }^{3}$
}

Keywords :

Kemampuan Koneksi

Matematis, Tingkat Berpikir

Van Hiele, Kubus dan Balok
ABSTRACT
Penelitian ini bertujuan untuk: (1) Mendeskripsikan

kemampuan koneksi matematis siswa pada materi kubus dan balok. (2) Mengetahui kesalahan kemampuan koneksi matematis siswa pada materi kubus dan balok. (3) Mengetahui faktor penyebab kesalahan kemampuan koneksi matematis siswa pada materi kubus dan balok. Jenis penelitan ini adalah penelitian deskriptif analitis. Subjek dalam penelitian ini adalah siswa kelas VIII Mts Al-Fatah Singkawang, dan objeknya adalah kemampuan koneksi matematis siswa pada kubus dan balok. Berdasarkan hasil analisis diperoleh: untuk indikator 1 yaitu mengenali dan memanfaatkan hubungan-hubungan antar gagasan matematika rata-ratanya adalah 66,67\% dengan kategori sedang; untuk indikator 2 yaitu memahami bagaimana gagasan-gagasan dalam matematika saling berhubungan dan mendasari satu sama lain untuk menghasilkan suatu keutuhan yang koheren rata-ratanya adalah $26,11 \%$ dengan kategori rendah; untuk indikator 3 yaitu mengenali dan menerapkan matematika dalam konteks-konteks diluar matematika atau masalah kehidupan sehari-hari rata-ratanya adalah 0,36,\% dengan kategori rendah. Bentuk kesalahankesalahan koneksi matematis siswa antara lain; (1) tidak mampu memahami masalah. (2) salah memaknai soal. (3) kesalahan konsep dan salah menentukan rumus. (4) kesalahan prosedur, (5) kesalahan dalam mengubah bahasa sehari-hari ke dalam bentuk matematika. (6) kesalahan dalam menuliskan langkah-langkah penyelesaian soal cerita kubus dan balok. Factor-faktor yang mempengaruhi siswa antara lain; (1) kurangnya dalam memahami masalah dan kurangnya kemampuan siswa dalam melakukan proses pengukuran dan penentuan suatu konsep, (2) kurangnya kemampuan siswa dalam mengungkapkan ide-ide yang ia miliki untuk menyelesaikan soal yang diberikan dan siswa kurang teliti melihat hubungan-hubungan apa dari data yang ada, (3) kurangnya kemampuan siswa dalam mengubah soal dalam bahasa sehari-hari kedalam bentuk matematika. Hasil 
penelitian menunjukan bahwa persentase siswa dalam memecahkan masalah geometri berdasarkan teori Van Hiele masih berada pada kategori rendah. Jadi dari hasil penelitian didapat bahwa siswa yang memiliki kemampuan koneksi berdasarkan tingkat berpikir level 2 berada di kategori sedang sedangkan kemampuan koneksi dengan tingkat berpikir level 1 dan level 0 berada pada kategori rendah..

\section{INTRODUCTION}

Pendidikan merupakan suatu proses perubahan tingkah laku dan kemampuan seseorang menuju ke arah yang lebih baik berupa kemajuan dan peningkatan. Ghufron (2017) mengungkapkan bahwa pendidikan adalah upaya sadar yang dilakukan untuk meningkatkan kemampuan individu agar dapat menentukan kehidupan secara mandiri. Pendidikan mempunyai peranan yang sangat penting bagi kehidupan manusia. Sehingga dengan adanya pendidikan seorang individu dapat menentukan kehidupan yang lebih baik dan tidak bergantung kepada orang lain. Tujuan pendidikan pada umumnya adalah menyiapkan individu yang dapat membentuk manusia berwawasan luas dan berpikir kreatif serta mandiri sehingga mampu memecahkan permasalahan-permasalahan yang dihadapi serta dapat memberikan solusi untuk sebuah permasalahan yang diberikan terutama pada permasalahn matematika.

Matematika merupakan salah satu komponen dari serangkaian mata pelajaran yang mempunyai peranan penting dalam pendidikan (Sundayana, 2014: 2). Selain itu, matematika merupakan ilmu yang terstruktur dan saling berkaitan antara satu topik dengan topik lainnya (Romli, 2016). Sebagai ilmu yang saling berkaitan, siswa harus memiliki kemampuan dalam menghubungkan antara topik di dalam matematika. Kemampuan untuk menghubungkan kemampuan tersebut, terdapat lima kemampuan yang harus dimiliki siswa dalam belajar matematika yangb telah ditetapkan oleh The National Council of Teachers of Mathematics (dalam Musriliani dkk, 2015) salah satunya yaitu kemampuan koneksi.

Sesuai dengan yang dikemukakan NCTM (2000) mengenai perlunya mengembangkan pemahaman dan penggunaan keterkaitan (koneksi) matematika dalam ide atau pemikiran matematika peserta didik. NCTM menyatakan bahwa program pembelajaran disekolah mulai dari taman kanak-kanak sampai dengan kelas XII seharusnya memungkinkan peserta didik untuk mengenali dan menggunakan koneksi antar ide-ide atau gagasan dalam matematika, memahami bagaimana keterkaitan atau koneksi ide-ide dalam matematika dan menyusunnya untuk menghasilkan suatu hubungan yang koheren, serta mengenali dan menawarkan matematika dalam konteks-konteks permasalahan diluar matematika.

Kemampuan koneksi merupakan salah satu kemampuan berpikir tingkat tinggi yang sangat penting dan harus dikembangkan karena dalam pembelajaran matematika setiap konsep berkaitan satu sama lainnya. Standar kemampuan koneksi dalam pembelajrana matematika yaitu mengenal dan menggunakan hubungan diantara ide-ide matematis, memahami bagaimana ide matematika saling berhubungan dan membangun ide satu sama lain untuk menghasilkan keseluruhan yang saling terkait, mengenal dan menerapkan ilmu matematika diluar konteks matematika (Musriliani, 2015:2). Melalui aturan matematika dengan bidang studi lain, pada aspek ini siswa mampu mengaitkan konsep matematika ke ilmu lain untuk memecahkan suatu masalah, mencari dan memahami antara konsep atau aturan matematika dengan aplikasi pada kehidupan nyata, pada aspek ini siswa mampu memecahkan masalah yang berkaitan dengan kehidupan sehari-hari dengan menggunakan konsep matematika. Dapat disimpulkan kemampuan koneksi matematis siswa adalah kemampuan siswa dalam menghubungkan antar konsep matematika itu sendiri maupun dengan ilmu selain matematika atau dalam kehidupan sehari-hari. 
Bruner menyatakan bahwa anak perlu menyadari bagaimana hubungan antar konsep, karena antara sebuah bahasan dengan bahasan matematika lainnya saling berkaitan (Lestari 2014: 37). Selanjutnya Yuniawati $(2011 ; 106)$ menyatakan kemampuan koneksi matematik sangat penting untuk dimiliki siswa agar siswa mampu membuat suatu hubungan yang bermakna antar konsep matematika atau antara konsep dengan bidang lain ataupun dengan kehidupan atau lingkungan sekitar siswa. Selain itu, jika kemampuan koneksi telah dimiliki oleh siswa maka akan mempermudah siswa untuk memahami suatu konsep. Apabila siswa dapat menghubungkan konsep-konsep matematika, maka pemahaman mereka akan lebih mendalam dan lebih bertahan lama, namun jika siswa masih sulit menghubungkan materi yang mereka pelajari dengan prasyarat yang sudah mereka kuasai, maka konsep-konsep yang telah dipelajari tidak bertahan lama dalam ingatan siswa. Berdasarkan uraian tersebut peneliti berpendapat bahwa kemampuan koneksi matematis sangat penting dimiliki oleh setiap siswa, karena ilmu matematika merupakan satu kesatuan dan tidak saling terpisahkan dalam berbagai topik.

Namun kenyataannya dalam pembelajaran kemampuan koneksi siswa masih rendah hal ini diketahui dari hasil penelitian Sugiman (2008:10) yang mengungkapkan bahwa "rata-rata persentase penguasaan untuk setiap aspek koneksi adalah koneksi inter topik matematika 63\%, antar topik matematika $41 \%$, matematika dengan pelajaran lain 56\%, dan matematika dengan kehidupan 55\%". Kemudian didukung oleh penelitian Warih, dkk (2016) menunjukan bahwa siswa melakukan kesalahan pada indikator menggunakan hubungan diantara ide-ide matematis dan siswa belum dapat menghubungkan satu konsep dengan konsep lain yang sudah dipelajari untuk menyelesaikan soal koneksi matematis, siswa tidak mengenali ide-ide matematis, dan siswa tidak dapat menggunakan ideide matematis. Berdasarkan hasil penelitian tersebut dapat diketahui bahwa kemampuan koneksi matematika masih rendah, khususnya dalam menyelesaikan soal matematika. Dalam menyelesaikan soal matematika, siswa hanya mempelajari apa yang diajarkan oleh guru tanpa mencari tahu dari sumber lain.

Hal ini juga didukung dari hasil prariset yang dilakukan peneliti pada hari Senin 13 Agustus 2018 di Mts Alfatah Singkawang dengan memberi satu soal yang mengandung salah satu indikator koneksi yaitu mengenali dan memanfaatkan hubungan-hubungan antar gagasan matematika kepada 30 orang siswa kelas VIII. Hasilnya menunjukan bahwa rata-rata kemampuan koneksi siswa tergolong masih rendah.

Dari hasil prariset diketahui $60 \%$ dari 30 orang siswa mengalami kesulitan dalam memahami soal. Pada soal yang diujikan siswa diminta untuk mencari keliling bangun persegi panjang yang diketahui luasnya yaitu $280 \mathrm{~cm}$ dan lebarnya adalah $14 \mathrm{~cm}$. Berdasarkan salah satu hasil pekerjaan siswa pada Gambar 1, siswa tidak dapat mencari keliling bangun persegi panjang dengan mengaitkan luas persegi panjang yang diketahui. Siswa melakukan kesalahan dalam menyelesaikan soal dengan langsung ke rumus keliling persegi. Cara yang dilakukan siswa tersebut tidak tepat untuk menyelesaikan soal yang diujikan. Pada Gambar 1 menunjukan bahwa kemampuan koneksi antar konsep matematika siswa masih rendah. Rendahnya kemampuan koneksi matematis siswa diduga karena pembelajaran masih didominasi oleh guru, sehingga peserta didik kurang terlibat secara aktif dalam pembelajaran. Salah satu penyebab timbulnya masalah tersebut adalah karena pembelajaran matematika hanya berfokus pada guru sehingga peserta didik tidak memiliki peranan dalam mengoneksikan permasalahan yang diberikan. Karena kurangnya peranan siswa dalam mengkoneksikan permasalahan menyebabkan siswa kesulitan dalam menyelesaikan soal kemampuan koneksi matematis siswa dan banyak siswa yang tidak tuntas dalam mengerjakan soal kemampuan koneksi matematis. Kurangnya kemampuan siswa dalam mengkoneksikan permasalahan tersebut juga didominasi oleh guru yang kurang dalam memberikan latihan-latihan soal koneksi, bahkan ada juga guru yang tidak memberikan latihan-latihan soal koneksi. terbukti dari hasil prariset, banyak siswa yang tidak tuntas dalam menyelesaikan soal yang mengandung salah satu indikator kemampuan koneksi. 
Banyak faktor yang menyebabkan siswa melakukan kesalahan dalam menyelesaikan soal matematika. Menurut Amir (2015:8) faktor-faktor penyebab kesalahan yang dilakukan siswa dalam menyelesaikan soal matematika dapat dipandang sebagai faktor kesulitan yang dialami siswa. Hal ini disebabkan siswa mengalami kesulitan dalam menyelesaikan soal dimungkinkan akan melakukan kesalahan menjawab sebaliknya siswa yang melakukan kesalahan menjawab dimungkinkan sebelumnya mengalami kesulitan. Salah satu faktor internal yang perlu diperhatikan saat siswa melakukan kesalahan adalah dengan cara gaya kognitif. Kognitif erat kaitannya dengan kemampuan seseorang untuk memproses informasi sebagai respon dari rangsangan yang berasal dari lingkungan. Karena kognitif merupakan bagian dari karakteristik siswa. Kognitif adalah kebiasaan seseorang dalam pengolahan informasi yang digunakan dalam proses belajar yaitu mengamati, berpikir, menyelesaikan masalah dan mengingat.

Dalam pembelajaran matematika, diperlukan beberapa keterampilan agar siswa dapat memahami materi, lancar menggunakan dan melakukan prosedur sehingga mampu menyelesaikan masalah dengan tepat dan benar. Keterampilan yang dimaksud adalah kemampuan melakukan proses dalam memahami isi dari materi matematika untuk mengahasilkan keahlian dalam matematika (Mariyam, Nindy Citroresmi P, Rika Wahyuni 2018: 66). Materi yang dipilih dalam penelitian adalah materi geometri, materi geometri merupakan salah satu materi yang ada di kelas VIII. Pertimbangan peneliti mengambil materi geometri karena materi geometri sangat mendukung kemampuan koneksi matematis siswa dan berdasarkan hasil wawancara dengan guru matematika di Mts Alfatah Singkawang diketahui rata-rata nilai ulangan harian siswa pada materi geometri sangat rendah, banyak siswa yang tidak tuntas dan harus melakukan perbaikan. Salah satu submateri pada materi geometri yang memerlukan kamampuan koneksi adalah submateri kubus dan balok.

Pembelajaran matematika disekolah hanya mengejar nilai saja tanpa memperhatikan mutu dan aspek matematika yang saling berhubungan akibatnya proses berpikir peserta didik menjadi terhambat sehingga peserta didik mengalami kesulitan dalam menyelesaikan masalah apalagi dalam mengkoneksikan antar permasalahan. Dalam pelaksanaan matematika didalam kelas umumnya hanya terfokus kepada ketercapaian target materi menurut buku ajar ataupun kurikulum, bukan pada materi yang siswa pelajari, hal ini menyebabkan siswa hanya mengahafal konsep dan tidak memahami maksud dari isinya (Nindy Citroresmi P., Nurhayati 2017: 13). Menurut Mulyana (2003) pengajaran geometri yang baik harus sesuai dengan kemampuan anak. Kemampuan anak dapat dilihat dari proses berpikir dan penerapan keterampilan dalam pemecahan masalah geometri. Penerapan teori Van Hiele diyakini dapat mengatasi kesulitan siswa dalam pemecahan masalah dalam geometri. Hal ini disebabkan karena teori Van Hiele menjelaskan perkembangan berpikir siswa dalam belajar geometri. Dengan demikian anak dapat memperkaya pengalaman dan cara berpikirnya, selain itu sebagai persiapan untuk meningkatkan tahap berpikirnya ke tahap yang lebih dari tahap sebelumnya.

Berdasarkan teori van Hiele (1954) siswa akan melalui lima tingkat (level) berpikir dalam memahami geometri, yaitu: tingkat 0 (visualisasi), tingkat 1 (analisis), tingkat 2 (deduksi informal), tingkat 3 (deduksi), dan tingkat 4 (rigor). Dalam setiap tingkat berpikir Van Hiele juga dibutuhkan keterampilan-keterampilan dasar dalam memecahkan masalah geometri yang berbeda-beda. Misalnya, untuk tingkat 0 (visualisasi) dan tingkat 1 (analisis) dilihat dari keterampilan verbal (verbal skill) mempunyai karakteristik yang berbeda, yaitu: untuk tingkat 0 (visualisasi) siswa hanya mampu mengelompokkan gambar segiempat dan memberikan nama jenis segiempat tersebut, sedangkan untuk tingkat 1 (analisis) siswa sudah dapat secara akurat menjelaskan sifat berbagai gambar segiempat.

Berdasarkan permasalahan yang telah dibahas sebelumnya maka penulis tertarik untuk melakukan penelitian dengan judul "Analisis Kemampuan Koneksi Matematis Siswa Dalam Memecahkan Masalah Geometri Berdasarkan Tingkat Berpikir Van Hiele di kelas VIII MTS Alfatah Singkawang" 


\section{METHOD}

Jenis penelitian yang dilakukan merupakan jenis penelitian deskriptif dengan pendekatan kualitatif. Tujuan dari penelitian ini adalah untuk mencari informasi serta mendeskriptifkan tingkat kemampuan koneksi matematis siswa dalam memecahkan masalah geometri berdasarkan teori Van Hiele.

Teknik pengumpulan data dalam penelitian ini adalah teknik pengukuran dan teknik komunikasi langsung. Menurut Nawawi (2013:224) teknik pengukuran adalah cara mengumpulkan data yang bersifat kuantitatif untuk mengetahui tingkat atau derajat aspek tertentu yang dibandingkan dengan norma tertentu pula sebagai satuan ukur yang relevan. Sedangkan teknik komunikasi langsung yang digunakan dalam penelitian ini yaitu melalui wawancara (interview). Wawancara ialah proses komunikasi atau interaksi untuk mengumpulkan informasi dengan cara tanya jawab antara peneliti dengan informan atau subjek penelitian. Pada hakikatnya wawancara merupakan kegiatan untuk memperoleh informasi secara mendalam tentang sebuah isu atau tema yang diangkat dalam penelitian. Wawancara merupakan proses pembuktian, maka bisa saja hasil wawancara sesuai atau berbeda dengan informasi yang telah diperoleh sebelumnya. Dalam penelitian ini wawancara akan dilakukan kepada 6 orang siswa yaitu 2 siswa dari kelompok atas, 2 siswa dari kelompok tengah dan 2 siswa dari kelompok bawah. Teknik ini dilakukan untuk mengetahui kesulitan siswa sehingga melakukan kesalahan dalam menyelesaikan soal koneksi matematis berdasarkan teori Van Hiele.

Teknik analisis data dalam penelitian ini adalah sebagai berikut: (a) Langkah pertama yang dilakukan peneliti yaitu pemilihan subjek dengan memberikan soal tes berupa soal tingkat berpikir Van Hile, kemudian hasil tes tingkat berpikir Van Hiele masing-masing siswa diperiksa dan diberi skor untuk masing-masing level/kategori. Dari data yang diperoleh siswa, kemudian peneliti mengelompokan siswa sesuai dengan kategori tingkat berpikir Van Hiele. Berdasarkan hasil penelitian yang dialkukan di Mts Al-Fatah Singkawang diperoleh 1 anak pada level previsualisasi, 10 anak pada level 0, 14 anak pada level 1, 5 anak pada level 2, dan tidak ada yang mencapai level 3 dan 4(b) Untuk menjawab permasalahan yang pertama yaitu tentang tingkat kemampuan koneksi matematis siswa dalam memecahkan masalah geometri berdasarkan tingkat berpikir Van Hiele di kelas VIII Mts Alfatah Singkawang. yaitu pemberian skor pada masing-masing tes digunakan perhitungan seperti penskoran kemudian menganalisis data tes (c) Untuk menjawab permasalahan yang ke-2 dan ke-3 yaitu yaitu kesalahan yang mempengaruhi siswa dalamm menyelesaikan soal geometri berdasarkan indikator kemampuan koneksi matematis siswa kelas VIII Mts Alfatah Singkawang, maka langkah-langkah yang digunakan adalah Memilih siswa untuk diambil sampelnya dan diwawancarai. Peneliti mengambil enam siswa, 2 siswa kelompok atas, 2 siswa kelompok tengah, dan 2 siswa kelompok bawah. Pemilihan siswa berdasarkan respon jawaban siswa berdasarkan tes kemampuan koneksi matematis, Mendeskripsikan data pada tiap butir soal yang kemudian dikelompokan berdasarkan variasi jawaban siswa pada tiap butir soal dan dimasukan kedalam tabel 3.11. Dari variansi jawaban siswa, dapat diketahui kesalahan-kesalahan apa saja yang dilakukan siswa dan banyaknya faktor yang mempengaruhi siswa melakukan kesalahan terutama pada tiap aspek kemampuan koneksi matematis siswa dalam menyelesaikan soal geometri, menganalisis semua data berupa jawaban hasil wawancara tertulis yang terdapat di lembar jawaban sesuai dengan teknik analisis data interaktif disusun secara sistematis untuk kemudian diteliti dan dideskripsikan kemampuan koneksi setiap siswa sehingga dapat digunakan untuk melengkapi kesimpulan yang sebelumnya diperoleh dari pemberian tes tertulis.

\section{RESULTS AND DISCUSSIONS}

Hasil pengumpulan data selama penelitian diperoleh pemaparan hasil penelitian dilakukan secara terurut terhadap data dari subjek dengan kategori previsualisasi, subjek dengan kategori level 0 (Visualisasi), subjek dengan kategori level 1 (Analisis), dan subjek dengan kategori level 2 (Deduksi informal). Untuk data dengan kategori level 3 (Deduksi) dan kategori level 4 (Rigor) tidak bisa diungkap, sebab subjek tidak ada yang berada pada kategori level 3 dan level 4. Jika data ada yang kurang maka akan dipilih kembali subjek yang mewakili setiap kategori berdasarkan teori Van Hiele.. Selengkapnya dapat dilihat pada tabel 2. 
Table 1 Jumlah Siswa pada Masing-masing Kemampuan Siswa Berdasarkan Teori Van Hiele

\begin{tabular}{cccc}
\hline Level Berpikir & $\begin{array}{c}\text { Jumlah } \\
\text { Siswa }\end{array}$ & No Absen & Persentase \\
\hline $\begin{array}{c}\text { Previsualisasi } \\
\text { Level 0 }\end{array}$ & 1 & 8 & $3 \%$ \\
& 10 & $1,3,6,7,10,14,16,17,18$, & $33 \%$ \\
Level 1 & 14 & $2,5,9,12,13,15,21,23$, & $47 \%$ \\
& & $25,26,27,28,29,30$ & \\
Level 2 & 5 & $4,11,20,22,24$ & $17 \%$ \\
Level 3 & 0 & & $0 \%$ \\
Level 4 & 0 & & $0 \%$ \\
\hline
\end{tabular}

Dari tabel 2 diketahui bahwa Pengelompokan siswa pada tingkat perkembangan berpikir geometri Van Hiele tidak didasarkan pada perolehan nilai masing-masing siswa tetapi didasarkan pada kemampuan siswa dalam menjawab soal dari masing-masing tingkatan. Berdasarkan hasil tes diperoleh 1 anak pada level (previsualisasi), 10 anak pada level 0 (visualisasi), 14 anak pada level 1 (analisis), dan 5 anak pada level 2 (deduksi informal). Dalam penelitian ini diperoleh fakta bahwa siswa yang gagal mencapai tingkat sebelumnya, maka juga akan gagal mencapai tingkat selanjutnya. Hal ini sejalan dengan teori Van Hiele bahwa "semua anak mempelajari geometri dengan melalui tingkat tersebut dengan urutan yang sama dan tidak dimungkinkan adanya tingkat yang diloncat. Kemudian selanjutnya setelah terpilih enam subjek, subjek diminta mengerjakan soal kemampuan koneksi matematis yang telah dipersiapkan oleh peneliti. Pengumpulan data dilakukan dengan wawancara, think aloud dan hasil pekerjaan subjek, rata-rata hasil tes kemampuan koneksi siswa dapat dilihat pada tabel 3

Tabel 2 Kemampuan Koneksi Siswa pada Tiap Kategori

\begin{tabular}{ccccc}
\hline Kategori & Banyak Siswa & $\begin{array}{c}\text { Jumlah Nilai } \\
\text { Tes }\end{array}$ & $\begin{array}{c}\text { Rata-Rata } \\
\text { Nilai Tes }\end{array}$ & $\begin{array}{c}\text { Kategori } \\
\text { Rata- } \\
\text { RataTes }\end{array}$ \\
\hline Rendah & 23 & 510,4 & 22,19 & \\
Sedang & 4 & 280 & 70 & Sedang \\
Tinggi & 3 & 280 & 93,33 & \\
\hline Total & $\mathbf{3 0}$ & $\mathbf{1 0 7 0 , 4}$ & $\mathbf{3 5 , 8 8}$ & \\
\hline
\end{tabular}

Dari Tabel 4.3 di atas dapat terlihat bahwa kemampuan koneksi matematis siswa paling banyak berada pada kategori rendah, sedangkan kemampuan koneksi siswa yang berada pada kategori sedang dan tinggi hampir mempunyai jumlah yang sama. Hal ini berarti bahwa rata-rata kemampuan koneksi matematis siswa kelas VIII Mts Al-Fatah Singkawang berada pada kategori sedang. Untuk melihat bagaimana kemampuan koneksi matematis siswa secara perindikator akan disajikan pada tabel 4

Tabel 3 Kemampuan Koneksi Matematis Siswa Perindikator

\begin{tabular}{cccc}
\hline \multicolumn{3}{c}{ Indikator } \\
\hline Jumlah & 1 & 2 & 3 \\
Rata-rata & 120 & 47 & 11 \\
$\%$ & 4 & 1,57 & 0,36 \\
\hline Kategori & 66,67 & 26,11 & 12,22 \\
\hline
\end{tabular}

Dari Tabel 4 di atas dapat terlihat bahwa rata-rata kemampuan koneksi matematis siswa dalam memecahkan masalah geometri berdasarkan teori berpikir Van Hiele pada tiap-tiap indikator mempunyai rata-rata tertinggi pada soal nomor 1 yang mana soal merupakan soal kemampuan koneksi 
antar gagasan matematika dan rata-rata kemampuan koneksi matematis siswa pada tiap-tiap indikator mempunyai rata-rata terendah pada soal nomor nomor 3 yang mana soal ini merupakan soal kemampuan koneksi matematika dengan kehidupan sehari-hari. Selain itu dari ketiga soal, rata-rata skor tertinggi siswa berada pada indikator pertama dan rata-rata skor terendah berada pada indikator ketiga.

Pengelompokan siswa dalam tingkat kemampuan koneksi matematis dapat dilihat dari tabel 4 analisis kemampuan koneksi matematis siswa dalam menjawab soal dari masing-masing indikator. Berdasarkan hasil tes diperoleh 3 siswa kriteria persentase tinggi, 6 siswa kriteria persentase sedang, dan 21 siswa kriteria persentase rendah.

a. Paparan dan Analisis Data Subjek dengan Tingkat Berpikir Level 2 subjek A4, berdasarkan analisis tes A4 mampu menuliskan apa yang diketahui dan apa yang ditanyakan, mampu mengaitkan apa yang diketahui dan apa yang ditanyakan, mampu mengaitkan hubungan antar rumus, mampu mengaitkan hubungan antar gagasan matematika,mampu mengaitkan matematika dengan konteks diluar matematika mampu melakukan perhitungan secara benar dengan hasil penyelesaian akhir secara tepat baik untuk soal no 1, 2, dan 3. Berdasarkan kutipan-kutipan wawancara A4 mampu menjawab pertanyaan peneliti secara tepat dari apa yang diketahui dan ditanyakan, mampu menjawab pertanyaan rumus apa yang digunakan untuk menentukan pertanyaan soal, mampu menjawab pertanyaan konsep rumus apa yang digunakan untuk penyelesaian soal, dan mampu menjawab pertanyaan yang berkaitan dengan kehidupan seharihari. Jadi dapat disimpulkan kemampuan koneksi matematis A4 berada pada kategori tinggi, karena A4 mampu mengenali dan memanfaatkan hubungan-hubungan antar gagasan matematika, memahami bagaimana gagasan-gagasan dalam matematika saling berhubungan dan mendasari satu sama lain untuk menghasilkan suatu keutuhan yang koheren, mengenali dan menerapkan matematika dalam konteks-konteks diluar matematika atau masalah kehidupan sehari-hari

b. Paparan dan analisis data subjek dengan tingkat berpikir level 2 subjek A11, Berdasarkan analisis tes A11 mampu menuliskan apa yang diketahui dan apa yang ditanyakan, mampu mengaitkan apa yang diketahui dan apa yang ditanyakan, mampu mengaitkan hubungan antar rumus, mampu mengaitkan hubungan antar gagasan matematika, mampu melakukan perhitungan secara benar dengan hasil penyelesaian akhir secara tepat untuk soal no 1 dan 2 walaupan A11 tidak menuliskan kesimpulan hasil akhir, dan untuk soal yang no 3 A11 mampu mengaitkan matematika dengan konteks diluar matematika tetapi dalam pengerjaannya A11 tidak biasa melakukan perhitungan dengan benar dan hasil penyelesaian akhirnya tidak tepat. Berdasarkan kutipankutipan wawancara A11 mampu menjawab pertanyaan peneliti secara tepat dari apa yng diketahui dan ditanyakan, mampu menjawab pertanyaan rumus apa yang digunakan untuk menentukan pertanyaan soal, mampu menjawab pertanyaan konsep rumus apa yang digunakan untuk penyelesaian soal, dan mampu menjawab pertanyaan yang berkaitan dengan kehidupan seharihari. Dapat disimpulkan kemampuan koneksi matematis A11 berada pada kategori tinggi, karena A11 mampu mengenali dan memanfaatkan hubungan-hubungan antar gagasan matematika, memahami bagaimana gagasan-gagasan dalam matematika saling berhubungan dan mendasari satu sama lain untuk menghasilkan suatu keutuhan yang koheren, mampu mengenali dan menerapkan matematika dalam konteks-konteks diluar matematika atau masalah kehidupan sehari-hari walaupun dalam pengerjaannya Subjek A11 salah dalam melakukan langkah-langkah penyelesaian.

c. Paparan dan analisis data subjek dengan tingkat berpikir level 1 subjek A5, Setelah diperoleh hasil pekerjaan tertulis dan analisis data wawancara, selanjutnya dilakukan perbandingan untuk mengetahui valid tidaknya data yang diperoleh. Berdasarkian hasil analisis tes, A5 mampu menuliskan apa yang diketahui dan apa yang ditanyakan secara tepat untuk soal no 1 dan 2 sedangkan untuk soal yang no 3 tidak dapat diprediksi karena A5 tidak menuliskan jawaban, A5 mampu mengaitkan hubungan antar rumus, mampu mengaitkan hubungan antar gagasan matematika, mampu melakukan perhitungan secara benar dengan hasil penyelesaian akhir secara tepat untuk soal no 1 walaupan A5 tidak menuliskan kesimpulan hasil akhir, untuk soal no 2 A5 
hanya bisa menjawab dengan benar untuk yang bagian a yaitu mencari nilai $\mathrm{x}$ sedang kan untuk bagian b A5 salah menggunakan rumus, dan untuk soal yang no 3 A5 tidak dapat diprediksi apakah A5 mampu mengaitkan matematika dengan konteks diluar matematika karena A5 tidak menuliskan jawaban sama sekali. Berdasarkan kutipan-kutipan wawancara A5 mampu menjawab pertanyaan peneliti secara tepat dari apa yang diketahui dan ditanyakan, mampu menjawab pertanyaan rumus apa yang digunakan untuk menentukan pertanyaan soal, mampu menjawab pertanyaan konsep rumus apa yang digunakan untuk penyelesaian soal, dan tetapi A5 tidak amamampu menjawab pertanyaan yang berkaitan dengan kehidupan sehari-hari. Dapat disimpulkan kemampuan koneksi matematis A5 berada pada kategori sedang, karena Er mampu mengenali dan memanfaatkan hubungan-hubungan antar gagasan matematika, memahami bagaimana gagasan-gagasan dalam matematika saling berhubungan dan mendasari satu sama lain untuk menghasilkan suatu keutuhan yang koheren walaupun A5 melakukan kesalahan dalam langkah-langkah penyelesaian, namun A5 belum mampu mengenali dan menerapkan matematika dalam konteks-konteks diluar matematika atau masalah kehidupan sehari-hari.

d. Paparan dan analisisi data subjek dengan tingkat berpikir level 1 subjek A15, Setelah diperoleh hasil analisis pekerjaan tertulis dan analisis data wawancara, selanjutnya dilakukan perbandingan untuk mengetahui valid tidaknya data yang diperoleh. Berdasarkian hasil analisis tes, A15 tidak mampu menuliskan apa yang diketahui dan apa yang ditanyakan secara tepat untuk soal no 1,2, dan 3, A15 mampu mengaitkan hubungan antar rumus, mampu mengaitkan hubungan antar gagasan matematika, mampu melakukan perhitungan secara benar dengan hasil penyelesaian akhir secara tepat untuk soal no 1 walaupan A15 tidak menuliskan kesimpulan hasil akhir, untuk soal no 2 A15 hanya bisa menjawab dengan benar untuk yang bagian a yaitu mencari nilai $\mathrm{x}$ sedang kan untuk bagian b A15 bingung dalam penggunakan rumus, dan untuk soal yang no 3 A15 mampu mengaitkan matematika dengan konteks diluar matematika tetapi A15 tidak mampu menyelesaikan soal tersebut. Berdasarkan kutipan-kutipan wawancara A15 mampu menjawab pertanyaan rumus apa yang digunakan untuk menentukan pertanyaan soal, mampu menjawab pertanyaan konsep rumus apa yang digunakan untuk penyelesaian soal, mampu menghubungkan antar rumus dalam matematika dan A15 mampu menjawab pertanyaan yang berkaitan dengan kehidupan sehari-hari tetapi tidak dapat menyelesaikan soal. Dapat disimpulkan kemampuan koneksi matematis A15 berada pada kategori sedang, karena Si mampu mengenali dan memanfaatkan hubungan-hubungan antar gagasan matematika, memahami bagaimana gagasangagasan dalam matematika saling berhubungan dan mendasari satu sama lain untuk menghasilkan suatu keutuhan yang koheren walaupun A15 melakukan kesalahan dalam langkah-langkah penyelesaian, namun A15 belum mampu mengenali dan menerapkan matematika dalam kontekskonteks diluar matematika atau masalah kehidupan sehari-hari walaupun Si melakukan kesalahan dalam penyelesaian soal.

e. Paparan dan analisis data subjek dengan tingkat berpikir level 0 subjek A10, setelah diperoleh hasil analisis data dan analisis data wawancara, selanjutnya dilakukan perbandingan untuk mengetahui valid tidaknya data yang diperoleh. Berdasarkan hasil analisis data tes A10 tidak mampu menuliskan apa yang diketahui dan apa yang ditanyakan secara tepat, tidak mampu mengaitkan hubungan antar rumus, tidak mampu mengaitkan hubungan antar gagasan matematika, dan tidak mampu melakukan perhitungan secara benar dengan hasil penyelesaian akhir untuk soal no 1, 2, dan 3. Berdasarkan kutipan-kutipan wawancara A10 tidak mampu memahami masalah, tidak bisa mengingat ketika ditanya mengenai rumus-rumus dalam bangun ruang, tidak bisa menyebutkan luas kubus dan volume balok, siswa tidak dapat membayangkan dan memahami soal, siswa benar-benar lupa materi persamaan linear, siswa tidak dapat menyimpulkan langkah-langkah yang harus dilakukan dalam menyelesaikan soal. Diperoleh kesimpulan kemampuan koneksi subjek A10 berada pada kategori rendah, karena A10 tidak mampu mengenali dan memanfaatkan hubungan-hubungan antar gagasan matematika, tidak memahami bagaimana gagasan-gagasan dalam matematika saling berhubungan dan mendasari satu sama lain untuk menghasilkan suatu keutuhan yang koheren, dan tidak mampu mengenali dan menerapkan matematika dalam konteks-konteks diluar matematika atau masalah kehidupan sehari-hari. 
f. Paparan dan analisis data subjek dengan tingkat level 0 subjek A17, setelah diperoleh hasil analisis pekerjaan tertulis dan analisis data wawancara, selanjutnya dilakukan perbandingan untuk mengetahui valid tidaknya data yang diperoleh. Berdasarkan hasil analisis data tes A17 tidak mampu menuliskan apa yang diketahui dan apa yang ditanyakan secara tepat, tidak mampu mengaitkan hubungan antar rumus, tidak mampu mengaitkan hubungan antar gagasan matematika, dan tidak mampu melakukan perhitungan secara benar dengan hasil penyelesaian akhir untuk soal no 1, 2, dan 3. Berdasarkan kutipan-kutipan wawancara A17 tidak mampu memahami masalah, tidak bisa mengingat ketika ditanya mengenai rumus-rumus dalam bangun ruang, tidak bisa menyebutkan luas kubus dan volume balok, siswa tidak dapat membayangkan dan memahami soal, siswa benar-benar lupa materi persamaan linear, siswa tidak dapat menyimpulkan langkah-langkah yang harus dilakukan dalam menyelesaikan soal, dan tidak mampu menghubungakan antaraa matematika dengan kehidupan sehari-hari. Diperoleh kesimpulan kemampuan koneksi subjek A17 berada pada kategori rendah, karena A17 tidak mampu mengenali dan memanfaatkan hubungan-hubungan antar gagasan matematika, tidak memahami bagaimana gagasan-gagasan dalam matematika saling berhubungan dan mendasari satu sama lain untuk menghasilkan suatu keutuhan yang koheren, dan tidak mampu mengenali dan menerapkan matematika dalam konteks-konteks diluar matematika atau masalah kehidupan sehari-hari.

Berdasarkan uraian diatas dapat disimpulkan bahwa siswa pada kelompok level 0 mempunyai kemampuan koneksi rendah, siswa pada level 1 mempunyai kemampuan koneksi sedang dan siswa level 2 mempunyai kemampuan koneksi tinggi, dan rata-rata kemampuan koneksi keseluruhan siswa Mts Al-Fatah berada pada kategori sedang yakni 35,88\% . Hal ini sejalan dengan penelitian setyorini (2016), secara keseluruhan, kemampuan koneksi matematis peserta didik kelas VIII E SMP Negeri 1 Grabag adalah rata-rata kemampuan koneksi antar topik dalam matematika berada dalam kategori sedang yakni 58,7\%, rata-rata kemampuan koneksi matematika dengan bidang ilmu lain berada dalam kategori sedang yakni 68,3\%, dan rata-rata kemampuan koneksi dengan kehidupan sehari-hari berada dalam kategori rendah yakni $40,3 \%$.

Adapun kesalahan kemampuan koneksi matematis siswa perindikator berdasarkan hasil tes Dalam penelitian ini diperoleh fakta bahwa siswa gagal dalam mencapai tingkat kemampuan koneksi matematis yang disebabkan oleh kesalahan-kesalahan berikut

Indikator 1, kesalahan yang dilakukan pada tahap ini adalah siswa tidak mampu memahami masalah apa yang diketahui dan ditanyakan hanya lebih pada proses hasil jawaban. Salah memaknai soal, mengabaikan kondisi soal, kesaalahan konsep dan salah menggunakan rumus.

Indikator 2, kesalahan yang dilakukan pada tahap ini yaitu kesalahan prosedur dan kesalahan dalam menggunakan rumus.

Indikator 3, kesalahan yang dilakukan pada tahap ini yaitu kesalahan dalam mengubah bahasa seharihari ke dalam bentuk matematika. Berdasarkan hasil tes dapat disimpulkan bahwa siswa sering melakukan kesalahan pada saat mengkoneksikan antarkonsep, antar ide-ide dalam matematika, dan antara matematika dengan konteks diluar matematika. Hal ini disebabkan siswa lebih fokus dalam memahami dan merencanakan penyelesaian. Hal ini sejalan dengan penelitian Koem (2014: 10) mengemukakan bahwa ada beberapa jenis kesalahan yang dilakukan siswa yaitu kesalahan konsep, kesalahan prinsip, kesalahan operasi dan kesalahan karena kecerobohan.

Faktor penyebab kesalahan kemampuan koneksi matematis siswa perindikator. Indikator yang pertama (mengenali dan memanfaatkan hubungan-hubungan antar gagasan dalam matematika) yaitu kurangnya pemahaman siswa dalam memahami masalah, kurangnya kemampuan siswa dalam memaknai soal dan kurangnya kemampuan siswa dalam melakukan proses pengukuran dan penentuan suatu konsep atau memahami konsep. Indikator yang kedua (memahami bagaimana gagasan-gagasan dalam matematika saling berhubungan dan mendasari satu sama lain) yaitu kurangnya kemampuan siswa dalam mengungkapkan ide-idenya yang ia miliki untuk menyelesaikan soal yang diberikan, siswa kurang 
teliti melihat hubungan-hubungan apa dari data yang ada, dan siswa mengalami kesulitan dalam melakukan perhitungan. Indikator yang ketiga (mengenali dan menerapkan matematika dalam konteks-konteks diluar matematika atau kehidupan sehari-hari) yaitu kurangnya kemampuan siswa dalam memaknai soal dan mengubahnya dalam bahasa sehari-hari kedalam bentuk matematika, kurangnya kemampuan siswa dalam megubah $\mathrm{cm}$ ke dm, dan kurangnya kemampuan siswa dalam membuat simpulan dari proses perhitungan dan penyelidikan yang telah dilaksanakan. Hal ini sejalan dengan penelitian Nuriyah (2015: 56) menyatakan bahwa ada dua faktor penyebab kesalahan siswa dalam pembelajaran matematika yaitu faktor internal (panca indera, minat siswa, keterampilan dan pengetahuan dasar siswa dan inteligensi siswa) dan faktor eksternal (guru, metode pembelajaran, keluarga dan sekolah)

\section{CONCLUSION AND SUGGESTION}

Berdasarkan hasil penelitian dan pembahasan pada bab sebelumnya, penelitian yang dilakukan peneliti di MTS Al-Fatah Singkawang dapat disimpulkan yaitu sebagai berikut

1. Kemampuan koneksi matematis siswa dalam memecahkan masalah geometri berdasarkan tingkat berpikir Van Hiele di kelas VIII MTS Al-Fatah Singkawang, a) persentase kemampuan siswa dalam memecahkan masalah pada indikator 1 sebesar 66,67\% dengan kategori sedang, b) persentase kemampuan siswa dalam memecahkan masalah pada indikator 2 sebesar $26,11 \%$ dengan kategori rendah, dan c) Persentase kemampuan siswa dalam memecahkan masalah pada indikator 3 sebesar $0,36 \%$ dengan kategori rendah

2. Kesalahan kemampuan koneksi matematis siswa yaitu; a) Indikator 1 kesalahan yang dilakukan pada tahap ini adalah siswa tidak mampu memahami masalah apa yang diketahui dan ditanyakan hanya lebih pada proses hasil jawaban. Salah memaknai soal, mengabaikan kondisi soal, kesaalahan konsep dan salah menggunakan rumus, b) Indikator 2 kesalahan yang dilakukan pada tahap ini yaitu kesalahan prosedur dan kesalahan dalam menggunakan rumus, dan c) Indikator 3 kesalahan yang dilakukan pada tahap ini yaitu kesalahan dalam mengubah bahasa sehari-hari kedalam bentuk matematika.

3. Faktor penyebab siswa melakukan kesalahan kemampuan koneksi matematis yaitu; a) Fakta bahwa sebagian besar siswa ketidakmampuan siswa mencapai indikator yang pertama disebabkan oleh factor (siswa tidak mampu memahami masalah, siswa tidak mampu dalam memaknai soal, dan siswa tidak mampu dalam melakukan proses pengukuran dan penentuan suatu konsep atau memahami konsep), b)Fakta bahwa sebagian besar tidak mampu mencapai indikator yang kedua disebabkan oleh factor (Siswa tidak mampu dalam mengungkapkan ide-idenya yang ia miliki untuk menyelesaikan soal yang diberikan, siswa kurang teliti melihat hubungan-hubungan apa dari data yang ada, dan siswa mengalami kesulitan dalaam melakukan perhitungan), c) Fakta bahwa sebagian besar siswa tidak mampu mencapai indikator yang ketiga disebabkan oleh factor (Siswa tidak mampu dalam memaknai soal dan mengubahnya dalam bahasa sehari-hari kedalam bentuk matematika, siswa tidak mampu megubah $\mathrm{cm}$ ke dm, dan siswa tidak mampu membuat simpulan dari proses perhitungan dan penyelidikan yang telah dilaksanakan

\section{ACKNOWLEDGMENTS}

Berdasarkan kesimpulan di atas terdapat beberapa saran yang dapat penulis sampaikan pada penelitian ini sebagai berikut:

1. Bagi Guru

Guru sebaiknya perlu sesekali mengasah kemampuan koneksi matematis siswa, agar siswa dapat mengaitkan matematika dalam kehidupan sehari-hari ataupun dengan bidang studi lain dan siswa dapat mengetahui kaitan antar topik matematika. Siswa dapat sering diberikan contoh soal latihan dengan menggunakan kemampuan koneksi matematis, agar siswa bisa dan terbiasa untuk menyelesaikan soal yang memerlukan kemampuan koneksi matematis

2. Bagi Siswa 
Siswa diharapkan agar lebih banyak mengulang kembali pelajaran yang sudah dipelajari, dan belajar untuk bisa fokus terhadap pelajaran tanpa mebuat keributan dan menggangu teman.

3. Bagi Peneliti

Peneliti diharapkan agar dapat menambah pengalaman dan menjadi masukan bagi peneliti lain untuk dapat dijadikan penunjang penelitian terhadap masalah yang sesuai dengan topik tersebut, serta untuk menambah wawasan baik dalam bidang penulisan maupun penelitian.

4. Bagi Peneliti Lain

Peneliti lain disarankan agar dapat melakukan penelitian lanjutan untuk mengetahui faktor yang menyebabkan siswa dengan kategori tinggi, sedang dan rendah, kemampuan koneksi dan belum mampu untuk menyelesaikan masalah kemampuan koneksi dengan baik.

\section{REFERENCES}

Amir, Muhammad Faizal. (2017). Analisis kesalahan mahasiswa PGSD Universitas Muhammadiyah Sidoarjo dalam meyelesaikan Soal Pertidaksamaan Linear. Jurnal Edukasi. Kajian Ilmu Pendidikan. 1(2), 131-146.

Lestari, k.. (2014). Implementasi Brain-Based Learning Untuk Meningkatkan Kemampuan Koneksi dan Kemampuan Berpikir Kritis Serta Motivasi Belajar Siswa SMP. Jurnal Pendidik. USINKA, 2(1), 36-46

Lestari, Kurnia Eka dan Yudhanegara, Mohammad Ridwan. (2015). Penelitian Pendidikan Matematika, Panduan Praktis Menyusun Skripsi, Tesis, dan Laporan Penelitian dengan Pendekatan Kuantitatif, Kualitatif, dan Kombinasi Disertai dengan Model Pembelajaran dan Kemampuan Matematis. Bandung: PT Refika Aditama.

Mulyana, E. (2003). Masalah Ketidaktepatan Istilah dan Simbol dalam Geometri SLTP kelas 1. Makalah FPMIPA UPI

Musriliani, dkk. (2015). Pengaruh Pembelajan Contextual Teching Learning (CTL) terhadap Kemampuan Koneksi Matematis Siswa SMP Ditinjau dari Gender. Jurnal Didaktik Matematika. 2( 2), 49-58.

Mariyam, dkk. (2018). Pengembangan Kemampuan Pemecahan Masalah Matematis Siswa pada Materi Pertidaksamaan Linear Satu Variabel Melalui Model Problem Based Learning Berbantuan Modul. JPMI(Jurnal Pendidikan Matematika Indonesia). 3(2), 66-73.

Nawawi, Hadari. (2015). Metode Penelitian di Bidang Sosial. Yogyakarta: Gadjah Mada University Press.

National Council of Teacher of Mathematics (NCTM).(2000). Principles and Standars for School Mathematics. Virginia: Reston.

Nuriyah, Fajar E. (2015). Analisis Kesalahan Siswa dalam Menyelesaikan Soal Matematika Materi Pokok Persamaan dan Fungsi Persamaan Kuadrat pada Siswa Kelas x MIA SMA Negeri 2 Wonosari. Skripsi. Universitas Negeri Yogyakarta

Prihatiningtyas, Nindy C. \& Nurhayati. (2017). Penerapan Model Pembelajaran Means-Ends Analysis Untuk Meningkatkan Kemampuan Pemecahan Masalah Matematis Siswa. JPMI (Jurnal Pendidikan Matematika Indonesia), 2(1), 13-18.

Romli, Muhammad. (2016). Profil kemampuan koneksi matematis siswa perempuan SMA dengan kemampuan tinggi dalam menyelesaikan masalah matematika. Journal of mathematics education, science \& tehnology. 1(2), 145-157.

Sugiman. (2008). Koneksi Matematik dalam Pembelajaran Matematika di Sekolah Menengah Pertama. Jurnal Pendidikan Matematika. 4(1), 56-66.

Sundayana. (2014). Statistika Penelitian Pendidikan. Bandung: Penerbit Alfabeta

Warih, dkk. (2016). Analisis Kemampuan Koneksi Matematis Siswa Kelas VIII Pada Materi Teorema Phytagoras. In Prosiding Konferensi Nasioanal Penelitian Matematika dan Pembelajarannya (KNPMP 1). Diselenggarakan oleh Program Studi Pendidikan Matematika, UMS, 12 Maret 2016, (hal. 377-384). Muhammadiyah University Press. Diakses dari https://publikasiilmiah.ums.ac.id/hadle/2502/6526 


\section{Journal of Educational Review and Research}

Vol. 1 No. 2, December 2018: 1 - 3

e-ISSN: 2597-9760, p-ISSN: 2597-9752

Widarti (2013). Kemampuan Koneksi Matematis dalam Menyelesaikan Masalah Kontekstual Ditinjau dari Kemampuan Matematis siswa. Skripsi. Pendidikan Matematika STKIP PGRI Jombang.

Yuniawati. (2011). Penerapan Pembelajaran Matematika dengan Strategi React untuk meningkatkan kemampuan koneksi dan Representasi Matematis Siswa Sekolah Dasar. Jurnal Edisin Khusus No 2 